\title{
UPAYA MENINGKATKAN HASIL BELAJAR SISWA DENGAN MENGGUNAKAN MODEL PEMBELAJARAN CONTEXTUAL TEACHING AND LEARNING PADA SUBTEMA PERUBAHAN LINGKUNGAN
}

\author{
Abdul Mumin Saud, S.Sos.,M.Pd ${ }^{1}$ \\ Fatimah Zahra Azhari ${ }^{2}$ \\ 1Dosen Universitas Pasundan \\ 2Mahasiswa Universitas Pasundan \\ 1abdulmuminsaud@unpas.ac.id \\ 2fatimah_zahra@gmail.com
}

\begin{abstract}
This research is based on the result of initial observation of research in class $\checkmark$ SDN Karangsari, Haurwangi Subdistrict, Cianjur Regency, found the problem on the subtheme of environmental change that is low student learning result. Along with these problems the purpose of this study is to improve student learning outcomes in class $V$ on subtema environmental changes. In the implementation of this study conducted three cycles, the subject of research is the students of class $V$ SDN Karangsari which amounted to 38 people consisting of 16 men and 22 women. Acquisition of learning outcomes in classroom action research on the first cycle of learning outcomes as much as $39.47 \%$ or as many as 15 people expressed in complete, the second cycle as much as $52.63 \%$ or as many as 20 people expressed complete, while in cycle III as much $86.84 \%$ Or as many as 33 people are declared complete, students who are declared complete the value of the students who meet the (KKM) which has been set that is 70 . This shows the results of research using Contextual Teaching and Learning learning model on subtema environmental changes in class $V$ SDN Karangsari occurred An increase in each cycle and can be stated successfully improve student learning outcomes.
\end{abstract}

Keywords: Learning Contextual Teaching and Learning Model and Learning Outcomes

\section{ABSTRAK}

Penelitian ini dilatarbelakangi hasil observasi awal penelitian di kelas $\mathrm{V}$ SDN Karangsari Kecamatan Haurwangi Kabupaten Cianjur, ditemukan permasalahan pada subtema perubahan lingkungan yaitu hasil belajar siswa rendah. Seiring dengan permasalahan tersebut tujuan penelitian ini adalah meningkatkan hasil belajar siswa di kelas $\mathrm{V}$ pada subtema perubahan lingkungan. Dalam pelaksanaan penelitian ini dilakukan tiga siklus, subjek 
penelitiannya adalah siswa kelas V SDN Karangsari yang berjumlah 38 orang yang terdiri dari 16 laki-laki dan 22 perempuan. Perolehan hasil belajar dalam penelitian tindakan kelas pada siklus I presentase hasil belajar sebanyak $39,47 \%$ atau sebanyak 15 orang yang dinyatakan tuntas, pada siklus II sebanyak $52,63 \%$ atau sebanyak 20 orang yang dinyatakan tuntas, sedangkan pada siklus III sebanyak $86,84 \%$ atau sebanyak 33 orang yang dinyatakan tuntas, siswa yang dinyatakan tuntas merupakan siswa yang nilainya memenuhi (KKM) yang telah ditetapkan yaitu 70 . Hal ini menunjukan hasil penelitian dengan menggunakan model pembelajaran Contextual Teaching and Learning pada subtema perubahan lingkungan di kelas V SDN Karangsari terjadi peningkatan setiap siklusnya dan dapat dinyatakan berhasil meningkatkan hasil belajar siswa.

Kata Kunci: Model Pembelajaran Contextual Teaching and Learning dan Hasil Belajar

\section{A. PENDAHULUAN}

Pendidikan

merupakan

kebutuhan setiap manusia untuk mengembangkan potensi yang ada dalam dirinya. Pendidikan itu sendiri bisa didapatkan melalui pembelajaran maupun pengalaman yang berasal dari lingkungan keluarga, lingkungan masyarakat, dan lingkungan sekolah. Pendidikan di sekolah diberikan melalui pembelajaran, bimbingan, dan latihan untuk mengembangkan potensi yang ada dalam diri peserta didik agar mampu menjadi seorang yang berguna dimasa yang akan datang.

$\begin{array}{lr}\text { Pendidikan bagi } & \text { sebagian } \\ \text { orang, berarti } & \text { berusaha } \\ \text { membimbing anak } & \text { untuk }\end{array}$

menyerupai orang dewasa dan pendidikan dapat mengembangkan potensi yang ada pada diri anak. Pendidikan menurut UU No. 20 Tahun 2003 dalam Rusman (2012, hlm, 20), Pendidikan adalah usaha sadar dan terencana untuk mewujudkan suasana belajar dan proses pembelajaran agar peserta didik secara aktif mengembangkan potensi dirinya untuk memiliki kekuatan spiritual keagamaan, pengendalian diri, kepribadian, kecerdasan, akhlak mulia serta keterampilan yang diperlukan dirinya, masyarakat, bangsa dan negara. Dari uraian di atas yang mengenai pendidikan bahwa, pendidikan adalah suatu yang terencana yaitu, sebuah proses 
yang disengaja dan dipikirkan secara matang.

Pendidikan merupakan suatu proses pembentukan kemampuan dasar, baik menyangkut daya pikiran atau emosional. Pendidikan menurut UU No.20 Tahun 2003 pasal 1 ayat 1 , pendidikan mewujudkan suasana belajar dan proses pembelajaran agar peserta didik secara aktif mengembangkan potensi dirinya, sesuai dengan yang di kehendaki pendidikan yang bersifat pengembangan dan humanis, yaitu berusaha mengembangkan segenap potensi didik bukan pembentukan secara behavioristik.

Pendidikan berfungsi untuk membangkan kemampuan dan keterampilan yang dimiliki seseorang hal ini pendidikan menngkatkan kesajahteraan dan tehindar dari kebodohan maupun kemiskinan. Sebagaimana pendidikan diatur dalam Undangundang Sistem Pendidikan Nasional (UUSPN) Nomor 20 Tahun 2003 dalam Syaiful Sagala (2011, hlm, 11) tentang Fungsi dan Tujuan Pendidikan Nasional, yaitu:

"Pendidikan

nasional berfungsi mengembangkan kemampuan dan membentuk watak serta peradaban bangsa yang bertujuan untuk berkembangnya potensi peserta didik agar menjadi manusia yang beriman dan bertakwa kepada Tuhan YME, berakhlak mulia, sehat, berilmu, cakap, kreatif, mandiri dan menjadi warga Negara yang demokratis serta bertanggung jawab".

Dalam Peraturan Pemerintah

No.19 tahun 2005 dalam Dadang Iskandar dan Narsim (2015, hlm, 14) bahwa Tujuan Pendidikan Dasar (BNSP: 2005) yaitu:

Untuk meletakan dasar kecerdasan, pengetahuan, kepribadian, akhlak mulia, serta keterampilan untuk hidup mandiri dan untuk mengikuti pendidikan lebih tinggi serta untuk mewujudkan tercapainya tujuan pendidikan diperlukan pembaharuan yang sesuai dengan peraturan perundang-undangan, sehingga pendidikan menajadi tanggung jawab semua pihak yang terkait di dalamnya, pada kenyataannya pendidikan bukanlah suatu upaya sederhana, melainkan suatu kegiatan yang 
dinamis dan penuh tantangan.

Pendidikan akan selalu berubah seiring perubahan jaman, itulah sebabnya pendidikan senantiasa memerlukan upaya perbaikan dan peningkatan sejalan dengan semakin tingginya kebutuhan dan tuntutan kehidupan masyarakat.

Oleh karena itu, pendidikan perlu mendapatkan perhatian yang besar agar negara Indonesia mampu mengejar ketinggalan dalam bidang ilmu pendidikan dan teknologi yang mutlak diperlukan untuk mempercepat pembangunan di Indonesia. Pendidikan yang harus diperhatikan terlebih dahulu adalah pendidikan pada tingkat dasar, karena pada tingkat pendidikan ini dituntut untuk menanamkan konsep yang kuat pada setiap mata pelajaran kepada siswa.

Sekolah merupakan salah satu lembaga pendidikan formal yang sangat berperan dalam mencerdaskan bangsa, dengan sumber daya manusia (SDM) yang cerdas maka secara otomatis kemajuan suatu bangsa akan semakin cepat. Pendidikan dasar khususnya SD sebagai salah satu jenjang pendidikan dasar, dalam proses pembelajaran harus lebih diarahkan pada pengembangan kemampuan dasar keterampilan berpikir pemahaman konsep sebagai dasar untuk menentukan langkah kedepan seseorang dalam melanjutkan jenjang pendidikannya. Maka penyelenggaraan pendidikan harus mampu menjamin pemerataan kesempatan, peningkatan mutu pendidikan untuk menghadapi tantangan sesuai dengan tuntutan perubahan kehidupan lokal, nasional, maupun global.

Maka Pemerintah Indonesia saat ini berusaha meningkatkan kualitas pendidikan di Indonesia. Perubahan yang dibuat pemerintah bertujuan untuk meningkatkan kualitas pendidikan di Indonesia yaitu dari kurikulum 1994, Kurikulum Berbasis Kompetensi (KBK) dan Kurikulum Tingkat Satuan Pendidikan (KTSP). Kurikulum Tingkat Satuan Pendidikan (KTSP) merupakan kurikulum penyempurnaan dari kurikulum sebelumnya yaitu 
Kurikulum Berbasis Kompetensi

(KBK). Perbahan kurikulum didasarkan pada UndangUndang Nomor 20 tahun 2003 tentang system Pendidikan Nasioanl dan Peraturan Pemerintah Nomor 19 tahun 2005 bahwa, "Standar Nasioanl Pendidikan akan memberikan peluang untuk menyempurnakan kurikulum yang komprehensif dalam rangka pencapaian Pendidikan Nasional". Kurikulum Tingkat Satuan Pendidkan (KTSP) merupakan kurikulum baru yang dikeluarkan Pemerintah Indonesia.

Kurikulum 2013 yang telah ditetapkan oleh pemerintah membuat pembelajaran yang ada di sekolah mengalami perubahan. Perubahan yang terjadi berupa mata pelajaran yang disatukan ke dalam satu buku, pembelajaran dilakukan dengan menggunakan tema tidak lagi berdasarkan nama mata pelajarannya. Dalam buku tema ini terdiri dari berbagai mata pelajaran yang disatukan sperti bahasa Indonesia, matematika, IImu Pengetahuan Sosial, IImu Pengetahuan Alam, Pendidikan
Kewarganegaraan, Seni budaya dan keterampilanp dan pendidikan jasmani olahraga kesehatan. Perubahan yanng lain seperti dalam penilaian yang dilakukan oleh guru. kurikulum ini dilakukan semata-mata untuk meningkatkan kualitas pendidikan yang ada di Indonesia. Akan tetapi guru kesulitan dalam menerapkan kurikulum 2013 apa lagi diperdesaan kebanyakan guru cenderung hanya terfokus pada buku dan guru sulit mengembangkan materi pembelajaran akibatnya siswa menjadi bingung dengan materi yang disampaikan.

Berdasarkan UndangUndang RI No 14 Tahun 2005 dalam Titut Hartadi (2011, hlm, 2) tentang guru dan dosen. Bab IV diantaranya menyatakan bahwa guru wajib memiliki kompetensi pedagogig, kepribadian, social dan professional. Pada bab IV bagian satu tentang kualifikasi, kompetensi dan sertifikasi pada pasal 18 yaitu sebagai berikut:

1) Kompetensi guru sebagaimana dimaksud dalam pasal 8 
meliputi

kompetensi

pedagogik,

kompetensi

kepribadian, kompetensi sosial

dan kompetensi profesional

yang diperoleh pendidikan profesi.

2) Ketentuan lebih lanjut mengenai kompetensi guru sebagaimana dimaksud ayat

(1) diatur dengan peraturan pemerintah.

Metode, model dan pendekatan banyak digunakan dalam kurikulum 2013 akan tetapi banyak guru yang kurang memahami tentang jenis-jenis metode, model, pendekatan yang digunakannya dan kurang tepat dalam memilih metode dan model pembelajaran.

Dalam melakasanakan proses mengajar guru masih menggunakan model ceramah, diskusi dan guru dalam pembelajaran jarang menggunakan media pembelajaran serta dalam proses pembelajaran lebih banyak guru berperan sebagai (teacher center) dibandingkan siswa yang aktif, kegiatan siswa selama proses pembelajaran hanya sebatas mendengarkan dan menulis.

Berdasarkan hasil observasi pada tanggal 6 januari 2017, penelitian yang di dapatkan dari wali kelas $\mathrm{V}$ SDN Karangsari dalam pembelajaran pada subtema perubahan lingkungan menunjukkan bahwa pada ulangan harian yang diadakan guru dalam subtema perubahan lingkungan dari 38 siswa hanya 18 orang yang mencapai KKM atau sekitar 30\% dan yang tidak mencapi KKM 20 orang atau sekitar 70\% KKM ditetapkan di sekolah adalah 70 .

Berdasarkan

hasil pengamatan yang telah dilakukan di SDN Karangsari, hasil belajar siswa rendah. Banyak sekali kendala yang terjadi pada saat pembelajaran, seperti kurangnya motivasi peserta didik dalam belajar, peserta didik pasif cenderung diam, daya ingatnya lemah, peserta didik kurang kerja sama ketika diskusi kelompok dan guru jarang menggunakan media dalam pembelajaran. Salah satu aktivitas yang lebih diutamakan dalam mencapai tujuan 
pembelajaran, salah satunya adalah kerjasama.

Kerjasama merupakan suatu kegiatan sekolompok untuk mengerjakan atau menyelesaikan suatu tugas secara bersama-sama dalam Badar al-Tabany Ibnu Trianto (2014, hlm 15), dalam kerjasama ini biasanya terjadi interaksi antara anggota kelompok dam mempunyai tujuan yang sama untuk dapat dicapai bersamasama. Menurut H. Kusnadi (2009) dalam Mangun Sigit Wardoyo (2013, hlm, 26) mengartikan kerja sama sebagai "dua orang atau lebih untuk melakukan aktivitas bersama yang dilakukan secara terpadu yang diarahkan kepada suatu target atau tujuan tertentu". Dari pertian kerja sama diatas, maka ada beberapa aspek yang terkandung dalam kerja sama, yaitu: "Dua orang atau lebih, artinya kerja sama akan ada kalau ada minimal dua orang/pihak yang melakukan

kesepakatan.

Berdasarkan pertanyaan diatas, maka sikap kerja sama merupakan aspek kepribadian yang penting dan perlu dimiliki setiap orang dalam kehidupan sosial di masyarakat ataupun di lingkungan sekolah.

Kontekstual (contextual) berasal dari kata context yang berarti "hubungan, konteks, suasana dan keadaan (konteks) " Adapun pengertian CTL menurut Tim Penulis Depdiknas (2003: 5) dalam Elaine b. Johnson (2011, hlm, 20) adalah sebagai berikut: Pembelajaran Konstektual adalah konsep belajar yang membantu guru mengaitkan antara materi yang diajarkannya dengan situasi dunia nyata siswa dan mendorong siswa membuat hubungan antara pengetahuan yang dimilikinya dengan penerapannya dalam kehidupan mereka sehari-hari, dengan melibatkan tujuh komponen utama pembelajaran efektif, yakni: kontruktivisme (contructivism), bertanya (questioning), menemukan (inquiry), masyarakat belajar (learning community), pemodelan (modeling), refleksi dan penelitian sebenarnya (authentic assessment). Sedangkan menurut Jhonson (2006: 67) dalam 
Dikusumah, Susanto Anry (2012, hlm, 20) yang mendefinisikan pembelajaran kontekstual (CTL) sebagai berikut: Sistem CTL adalah sebuah proses pendidikan yang bertujuan menolong para siswa melihat makna di dalam materi akademik yang mereka pelajari dengan cara menghubungkan subjek-subjek akademik dengan konteks dalam kehidupan keseharian mereka, yaitu dengan konteks pribadi, sosial dan budaya mereka.

Berdasarkan pendapat di atas Contextual Teaching and Learning (CTL) merupakan pembelajaran yang mengkaitkan dengan kehidupan sehari-hari atau dengan lingkungan sekitar. Pembelajaran Contextual Teaching and Learning (CTL) yaitu model yang mengajarkan kejadian yang benar-benar terjadi (nyata) di lingkungan tersebut siswa berada.

Menurut Komalasari (2008:6) dalam Ikka Rihhadatul A'isy (2012, hlm. 9) menjelaskan bahwa Model Kontekstual atau Contextual Teaching and Learning (CTL) pada hakikatnya merupakan konsep belajar yang membantu guru mengaitkan antara materi yang diajarkan dengan situasi dunia nyata peserta didik dan mendorong peserta didik membuat hubungan antara pengetahuan yang dimilikinya dengan penerapannya dalam kehidupan mereka sebagai anggota keluarga dan masyarakat, maupun warga negara dengan tujuan untuk menemukan makna materi tersebut bagi kehidupannya. Dalam konteks ini peserta didik perlu mengerti apa makna belajar, manfaatnya dalam status apa mereka memposisikan sebagai diri sendiri yang memerlukan suatu bekal yang bermanfaat untuk bekalnya nanti dan peserta didik akan berusaha untuk menggapinya.

Fokus penelitian disini adalah hasil belajar siswa. Hasil belajar siswa Nana Sudjana (2010:3) menyebutkan hasil belajar adalah: Perubahan tingkah laku siswa setelah melalui proses pembelajaran. Semua perubahan dari proses belajaran merupakan suatu hasil belajar dan 
mengakibatkan manusia berubah dalam sikap dan tingkah lakunya. Dari pendapat di atas dapat disimpulkan Hasil belajar adalah hasil yang dicapai oleh seorang siswa setelah melakukan suatu usaha untuk memenuhi kebutuhannya.

Menurut Bloom (dalam, Nana Sudjana 2010:3) hasil belajar dalam rangka studi yang dicapai melalui tiga kategori ranah yaitu ranah kognitif, afektif, psikomotor. Perinciannya adalah sebagai berikut:

a) Ranah Kognitif

Berkenaan dengan hasil belajar intelektual yang terdiri dari 6 aspek yaitu pengetahuan, pemahaman, penerapan, analisis, sintesis, dan penilian.

b) Ranah Afektif

Berkenaan dengan sikap dan nilai. Ranah afektif meliputi jenjang kemampuan yaitu menerima, menjawab atau reaksi, menilai, organisasi, karakterisasi, dengan suatu nilai atau kompleks nilai.

c) Ranah Psikomotor

Melalui gerakan refleksi, keterampilan pada gerakan- gerakan terbimbing, kemampuan perseptual (termasuk di dalamnya membedakan visual, auditif, motorif, dan gerakan-gerakan skill).

Berdasarkan pendapatpendapat di atas dapat disimpulkan bahwa hasil belajar adalah usaha yang digunakan untuk menghasilkan sebuah prestasi dan dibutuhkan perjuangan serta pengorbanan dan rasa optimis pada individu tersebut agar terjadi perubahan diri pada individu. Perubahan yang terjadi pada individu bukan hanya perubahan mengenai pengetahuan, tetapi juga untuk membentuk kecakapan, kebiasaan, pengertian, penguasaan, dan penghargaan dalam diri seseorang belajar.

Indikator keberhasilan belajar Syaiful Bahri Djamarah dan Aswan Zain (2006:106) dalam Anisah Himayani (2016, hlm, 14) mengemukakan bahwa indikator keberhasilan belajar, di antaranya yaitu:

1) Daya serap terhadap bahan pengajaran yang diajarkan 
mencapai prestasi tinggi, baik secara individual maupun kelompok

2) Perilaku yang di gariskan dalam tujuan pengajaran/instruksional khusus (TIK) telah dicapai oleh siswa, baik secara individual maupun kelompok.

Demikian dua macam tolak ukur yang digunakan sebagai acuan dalam menentukan tingkat keberhasilan proses belajar mengajar. Namun banyak dijadikan sebagai tolak ukur berhasilan dari keduanya ialah daya serap siswa terhadap pelajaran.

Berdasarkan uraian di atas dapat disimpulkan bahwa pembelajaran kontekstual merupakan sebuah strategi pembelajaran yang dianggap tepat untuk saat ini karena materi yang diajarkan oleh guru selalu dikaitkan dengan kehidupan sehari-hari siswa. Dengan menggunakan pembelajaran kontekstual, materi yang disajikan guru akan lebih bermakna. Siswa akan menjadi peserta aktif dan membentuk hubungan antara pengetahuan dan aplikasinya dalam kehidupan mereka.

Berdasarkan latar belakang di atas, penulis termotivasi untuk mencari jalan keluar atau solusi untuk masalah tersebut yang berjudul "Upaya meningkatkan hasil belajar siswa dengan menggunakan model pembelajaran Contextual Teaching and Learning (CTL) pada subtema perubahan lingkungan di kelas $\mathrm{V}$ SDN Bojongloa".

\section{B. LANDASAN TEORI}

1. Hasil belajar

a. Difinisi hasil pembelajaran

1) Pengertian hasil belajar menurut Bloom dalam Agus Suprijono (2015, hlm, 6) hasil belajar mencakup kemampuan kognitif, afektif, dan psikomotor.

2) Pengertian hasil belajar menurut Nana Sudjana (2013, hlm, 22) adalah kemampuankemampuan yang dimilki siswa setelah ia menerima pengalaman belajarnya.

3) Pengertian hasil belajar menurut Anni (2004:4) dalam Amila 
(2016, hlm, 76) merupakan perubahan perilaku yang diperoleh pembelajar setelah mengalami aktivitas belajar.

4) Pengertian hasil belajar menurut Soediarto (1993:49) dalam Etin Solihatin (2012, hlm, 6) hasil belajar sebagai tingkat penguasaan suatu pengetahuan yang dicapai oleh siswa dalam mengikuti program pembelajaran sesuai dengan tujuan pendidikan yang ditetapkan.

5) Pengertian hasil belajar menurut Gagnet dan Briggs (1979:45-51) dalam Etin Solihatin (2012, hlm, 6) mengklasifikasikan hasil belajar menjadi lima kategori, yaitu keterampilan intelektual, strategi kognitif, informasi verbal, keterampilan motorik dan sikap.

6) Pengertian hasil belajar menurut Sadly (1977: 904), yang memberikan penjelasan tentang hasil belajar sebagai berikut, "Hasil yang dicapai oleh tenaga atau daya kerja seseorang dalam waktu tertentu".
Berdasarkan pendapat di atas dapat disimpulkan bahwa hasil belajar adalah hasil yang dicapai dari suatu kegiatan pembelajaran atau perubahan tingkah laku seseorang setelah mengalami aktivitas belajar, hasil belajar bisa berupa angka atau perubahan sikap. Hasil mencakup kemampuan kognitif, afektif, dan psikomotor.

\section{b. Ciri-ciri hasil belajar}

Menurut Dimyati dan Mudjiono (2002) dalam Yuliana Nurrizki (2016, hlm 11) membagi beberapa ciri-ciri hasil belajar sebagai berikut:

1) Hasil belajar memiliki kapasitas berupa pengetahuan, kebiasaan, keterampilan sikap dan cita-cita

2) Adanya perubahan mental dan perubahan jasmani

3) Memiliki dampak pengajaran dan pengiring

c. Faktor-faktor yang mempengaruhi hasil belajar

Sugihartono, dkk.(2007:76-77) dalam Novi Berliani Ganisha (2016, hlm, 42), menyebutkan 
faktor-faktor yang mempengaruhi hasil belajar, sebagai berikut:

1) Faktor internal adalah faktor yang ada dalam diri individu yang sedang belajar. Faktor internal meliputi: faktor jasmaniah dan faktor psikologis

2) Faktor eksternal adalah faktor yang ada di luar individu. Faktor eksternal meliputi: faktor keluarga, faktor sekolah, dan faktor masyarakat. Faktor-faktor yang mempengaruhi hasil belajar di atas.

2. Model pembelajaran

\section{Contextual Teaching and Learning(CTL)}

a. Definisi model pembelajaran Contextual Teaching and Learning(CTL)

Menurut Elaine b. Johnson, Ph, D (2011, hlm, 23). CTL adalah sebuah sistem yang menyeluruh. CTL terdiri dari bagian-bagian yang saling terhubung. Jika bagian-bagian ini terjalin satu sama lain, maka akan dihasilkan pengaruh yang melebihi hasil yang diberikan bagian-bagiannya secara terpisah. Seperti halnya biola, cello, klarinet, dan alat musik lain di dalam sebuah orkestra yang menghasilkan bunyi yang berbedabeda yang secara bersama-sama menghasilkan musik, demikian juga bagian-bagian CTL yang terpisah melibatkan proses-proses yang berbeda, yang ketika digunakan secara bersam-sama, memampukan para siswa membuat hubungan yang menghasilkan makna. Setiap bagian CTL yang berbeda-beda ini memberikan sumbangan dalam menolong siswa memahami tugas sekolah. Secara bersama-sama, mereka membentuk suatu sistem yang memungkinkan para siswa melihat makna di dalamnya, dan mengingat materi akademik.

Menurut Komalasari (2008:6) dalam Ikka Rihhadatul A'isy (2012, hlm. 9) menjelaskan bahwa Model Kontekstual atau Contextual Teaching and Learning (CTL) pada hakikatnya merupakan konsep belajar yang membantu guru mengaitkan antara materi yang diajarkan dengan situasi dunia nyata peserta didik dan mendorong peserta didik membuat hubungan antara pengetahuan 
yang dimilikinya dengan penerapannya dalam kehidupan mereka sebagai anggota keluarga dan masyarakat, maupun warga negara dengan tujuan untuk menemukan makna materi tersebut bagi kehidupannya. Dalam konteks ini peserta didik perlu mengerti apa makna belajar, manfaatnya dalam status apa mereka memposisikan sebagai diri sendiri yang memerlukan suatu bekal yang bermanfaat untuk bekalnya nanti dan peserta didik akan berusaha untuk menggapinya.

Menurut Blanchard, dkk dalam Kokom Komalasari (2011, hlm. 06) mengemukakan bahwa: Contextual teaching and learning is a conception of teaching and learnng that helps teachers relate subject matter content to real world situations; and motivates students to make connections between knowledge and its applications to their lives as family members, citizens, and workers and engage in the hard work that learning requires.
CTL merupakan suatu konsep belajar dimana guru menghadirkan situasi dunia nyata kedalam kelas dan mendorong siswa membuat hubungan antara pengetahuan yang dimilikinya dengan penerapannya dalam kehidupan mereka sebagai anggota keluarga dan masyarakat.

Menurut Jhonson (2002: 24) dalam Kokom Komalasari (2011, hlm. 06) yang mendefinisikan pembelajaran kontekstual (CTL) sebagai berikut: "Contextual teaching and learning enables students to connet the content of academic subjects with the immediate context of their daily lives to discover meaning".

Pendekatan kontektual merupakan konsep belajar yang membantu guru mengaitkan antara materi yang diajarkan dengan situasi dunia nyata siswa dan mendorong siswa membantu hubungan antara pengetahuan yang dimilikinya dengan penerapannya dalam kehidupan mereka sebagai anggota keluarga dan masyarakat. Dengan konsep itu, hasil pembelajaran diharapkan 
lebih bermakna bagi siswa. proses pembelajaran berlangsung alamiah dalam bentuk kegiatan siswa bekerja dan mengalami, bukan mentranfer pengetahuan dari guru ke siswa.

Hakikat pembelajaran kontekstual dalam Zainal Aqib (2013, hlm 4), pembelajaran kontekstual adalah konsep belajar yang membantu guru mengaitkan antara materi yang diajarkan dengan situasi dunia nyata. Hal itu, mendorong siswa membantu hubungan antara pengetahuan yang dimilikinya dengan penerapannya dalam kehidupan mereka sehari-hari.

\section{b. Prinsip-prinsip}

model

\section{pembelajaran}

Contextual

\section{Teaching and Learning(CTL)}

CTL

(pembelajaran

kontekstual) sebagai pendekatan untuk belajar memiliki 7 prinsip.Prinsip-prinsip yang mendasari pelaksanaan proses pembelajaran dengan menggunakan CTL (pengajaran dan pembelajaran kontekstual) dalam Anisah Hilmayani (2016). Tujuh prinsip meliputi:
1) Konstruktivisme adalah proses membangun atau mengembangkan pengetahuan baru dalam struktur kognitif siswa berdasarkan pengalaman. Menurut konstruktivisme, pengalaman yang dipenuhi oleh luar, tapi dibangun oleh dan dari dalam diri sendiri.Oleh karena itu, pengalaman yang dibentuk oleh dua faktor penting yaitu objek menjadi subyek pengamatan dan kemampuan untuk menafsirkan objek.

2) Inquiri Prinsip kedua adalah penyelidikan dalam pembelajaran kontekstual. Artinya, proses pembelajaran didasarkan pada pencarian dan penemuan melalui proses berpikir sistematis. Pengetahuan bukanlah hasil dari mempertimbangkan sejumlah fakta, tetapi hasil dari proses menemukan sendiri. Dengan demikian dalam proses perencanaan, guru tidak mempersiapkan sejumlah bahan untuk dihafalkan, tetapi merangsang pembelajaran 
yang memungkinkan siswa untuk menemukan bahanbahan mereka sendiri untuk dipahami.

3) Pertanyaan Belajar pada dasarnya bertanya dan menjawab pertanyaan. Mempertanyakan dapat dianggap sebagai refleksi dari keingintahuan setiap individu, sedangkan menjawab pertanyaan mencerminkan kemampuan seseorang dalam berpikir. Dalam proses pembelajaran, guru tidak menyampaikan informasi begitu saja, tetapi daya tarik bagi siswa untuk menemukan diri mereka.

4) Belajar Komunitas Dalam pembelajaran kontekstual dan pembelajaran pelaksanaan komunitas belajar dapat dilakukan dengan menerapkan pembelajaran melalui kelompok belajar. Siswa dibagi dalam kelompokkelompok yang anggotanya heterogen baik dilihat dari kemampuan belajar dan kecepatan belajar.Mari saling belajar dalam kelompok mereka, yang dengan cepat mendorong untuk membantu peserta didik lambat.

5) Pemodelan adalah proses belajar sebagai contoh untuk menunjukkan sesuatu yang dapat ditiru oleh setiap siswa. Misalnya, guru memberikan contoh cara mengucapkan kalimat asing. Guru olahraga memberikan contoh tentang cara melempar bola dan sebagainya.

6) Refleksi adalah proses penyelesaian pengalaman yang telah dipelajari yang dilakukan dengan re-menyortir peristiwa atau kejadian yang telah melalui pembelajaran. Melalui refleksi atas pengalaman belajar yang akan dimasukkan dalam struktur kognitif siswa yang pada akhirnya akan menjadi bagian dari pengetahuan yang telah terbentuk.

7) Penilaian autentik adalah proses oleh guru untuk mengumpulkan informasi tentang kemajuan belajar 
siswa. Penilaian ini diperlukan untuk menentukan apakah siswa benar-benar belajar atau tidak.

Prinsip-prinsip Contecxtua Teaching and Learning (CTL) yaitu sebagai berikut:

1) Kesaling bergantungan (intedependensi), prinsip ini membuat hubungan yang bermakna atara proses pembelajaran dan konsteks kehidupan nyata sehingga peserta didik berkeyakinan bahwa belajar merupakan aspek yang esensial bagi kehidupan di masa datang.

2) Perbedaan (diferensiasi) adalah mendorong peserta didik menghasilkan keberagaman, perbedaan, dan keunikan. Terciptanya kemandirian dalam belajar yang dapat mengkonstruksi minat peserta didik untuk belajar mandiri dalam konsteks tim dengan mengkorelasikan bahan ajar dengan kehidupan nyata, dalam rangka mencapai tujuan secara penuh makna.
3) Pengaturan diri menyatakan bahwa proses pembelajaran diatur, dipertahankan, dan disadari oleh peserta didik sendiri, dalam rangka merealisasikan seluruh potensinya. Peserta didik secara sadar harus menerima tanggung jawab atas keputusan dan perilaku sendiri, menilai alternatif, membuat pilihan, mengembangkan rencana, menganalisis informasi, menciptakan solusi dan dengan kritis menilai bukti.

4) Penilaian Autentik yaitu menantang peserta didik agar dapat mengaplikasikan berbagai informasi akademis baru dan keterampilannya ke dalam situasi konstekstual secara signifikan.

c. Faktor-faktor yang dipertimbangkan dalam CTL Dalam Rusman (2012, hlm,87 ). Berikut ini merupakan beberapa faktor yang harus dipertimbangkan dalam metode contextual teaching and learning. 
1) Merencanakan pembelajaran sesuai dengan perkembangan mental peserta didik

2) Membentuk kelompok belajar yang saling bergantung

3) Mempertimabangkan keberagaman peserta didik

4) Menyediakan lingkunagn yang mendukung pembelajaran mandiri dengan tiga karekteristik umumnya yaitu, kesadaran berpikir, penggunaan strategi, dan motivasi berkelanjutan

5) Memerhatiakn multi-intelegansi

6) Menggunakan teknik bertanya dalam rangka meningkatkan peserta didik dalam pemecahan masalah dan keterampilan berpikir tingkat tinggi.

7) Mengembangkan pemikiran bahwa peserta didik akan belajar lebih bermakna jika ia diberi kesempatan untuk belajar menemukan dan mengkontruksi sendiri pengetahuan dan keterampilan baru.

8) Memfasilitasi kegiatan penemuan, supaya peserta didik memperoleh pengetahuan dan keterampilan melalui penenmuan sendiri.
9) Mengembangkan rasa ingin tahu di kalangan peserta didik melalui pengajuan pertanyaan

10) Menciptakan masyarakat belajar dengan membangun kerja sama di antara peserta didik

11) Memodelkan sesuatu agar peserta didik dapat beridentifikasi dan berimitasi dalam rangka memperoleh pengetahuan dan keterampilan baru.

12) Mengarahkan peserta didik untuk merefleksikan tentang apa yang sudah dipelajari dan menerapkan penilaian autentik

\section{d. Komponen CTL}

Dalam Rusman (2012, hlm. 192), beberapa komponen yang ada di dalam metode contextual teaching and learning adalah sebagai berikut.

1) Konstruksivisme

Contextual teaching and learning dibangun dalam landasan konstruktivisme yang memiliki anggapan bahwa pengetahuan dibangun peserta didik secara sedikit demi sedikit dan hasilnya diperluas melalui konsteks 
terbatas.Peserta didik harus

mengkonstruksi pengetahuan baru secara bermakna melalui pengalaman nyata.

1) Menemukan (inquiry), proses pembelajaran yang dilakukan peserta didik merupakan proses menemukan terhadap sejumlah pngetahuan dan keterampilan. Prose inquiry terdiri atas: a. Pengamatan, b. Bertanya, c. Mengajukan dugaan, d. Pengumpulan data, e. Penyimpulan

2) Betanya, proses pembelajaran dilakukan peserta didik diawali dengan proses bertanya. Proses bertanya yang dilakukan peserta didik sebenarnya merupakan proses berpikir yang dilakukan peserta didik dalam rangka memecahkan masalah dalam kehidupannya.

3) Masyarakat belajar, proses pembelajaran merupakan proses kerja sama antara peserta didik dengan peserta didik, antara peserta didik dengan gurunya dan antara peserta didik dengan lingkungan.
4) Pemodelan, proses pembelajaran akan lebih berarti jika didukung dengan adanya pemodelan yang dapat ditiru, baik yang bersifat kejiwaan maupun yang bersifat fisik yang berkaitan dengan cara untuk mengoperasikan sesuatu aktivitas, cara untuk menguasai pengetahuan atau keterampilan tertentu.

5) Refleksi adalah cara berpikir tentang apa yang baru dipelajarinya atau berpikir ke belakang tentang apa-apa yang sudah dilakukan atau dipelajari di masa lalu.

6) Penilaian yang sebenarnya, penilai merupakan proses pengumpulan data yang dapat mendeskripsikan mengenai perkembangan perilaku peserta didik. Pembelajaran efektif adalah proses membantu peserta didik agar mampu mempelajari bukan hanya menekankan pada diperolehnya sebanyak mungkin informasi di akhir periode pembelajaran. 
e. Langkah-langkah pembelajaran

Contextual

Teaching and Learning(CTL)

CTL dapat diterapkan dalam kurikulum apa saja, bidang studi apa saja, dan kelas yang bagaimanapun keadaannya. Pendekatan CTL dalam kelas cukup mudah dalam Zainal Aqib (2013, hlm 6). Secara garis besar, langkah-langkah yang harus ditempuh dalam CTL adalah sebagai berikut:

1) Kembangkan pemikiran bahwa siswa akan belajar lebih bermakna dengan cara bekerja sendiri, dan mengkonstruksi sendiri pengetahuan dan keterampilan barunya.

2) Laksanakan sejauh mungkin kegiatan inkuiri untuk semua topik.

3) Kembangkan sifat ingin tahu siswa dengan bertanya.

4) Ciptakan masyarakat belajar.

5) Hadirkan model sebagai contoh pembelajaran.

6) Lakukan refleksi di akhir pertemuan.

7) Lakukan penilaian yang sebenarnya (authentic assessment) dengan berbagai cara.

f. Kelebihan

model pembelajaran Contextual Teaching and Learning (CTL)

Adapun beberapa keunggulan dari pembelajaran Kontekstual adalah:

1) Pembelajaran menjadi lebih bermakna dan riil. Artinya siswa dituntut untuk dapat menagkap hubungan antara pengalaman belajar di sekolah dengan kehidupan nyata. Hal ini sangat penting, sebab dengan dapat mengorelasikan materi yang ditemukan dengan kehidupan nyata, bukan saja bagi siswa materi itu akan berfungsi secara fungsional, akan tetapi materi yang dipelajarinya akan tertanam erat dalam memori siswa, sihingga tidak akan mudah dilupakan.

2) Pembelajaran lebih produktif dan mampu menumbuhkan penguatan konsep kepada siswa karena metode pembelajaran CTL menganut aliran konstruktivisme, dimana seorang siswa dituntun untuk 
menemukan pengetahuannya

sendiri. Melalui landasan

filosofis konstruktivisme siswa diharapkan belajar melalui "mengalami" bukan "menghafal".

3) Kontekstual adalah model pembelajaran yang menekankan pada aktivitas siswa secara penuh, baik fisik maupun mental.

4) Kelas dalam pembelajaran Kontekstual bukan sebagai tempat untuk memperoleh informasi, akan tetapi sebagai tempat untuk menguji data hasil temuan mereka di lapangan.

5) Materi pelajaran dapat ditemukan sendiri oleh siswa, bukan hasil pemberian dari guru

6) Penerapan pembelajaran Kontekstual dapat menciptakan suasana pembelajaran yang bermakna

g. Kelemahan model pembelajaran Contextual Teaching and Learning(CTL) Kelemahan dari pembelajaran Kontekstual adalah sebagai berikut:
1) Diperlukan waktu yang cukup lama saat proses pembelajaran Kontekstual berlangsung.

2) Jika guru tidak dapat mengendalikan kelas maka dapat menciptakan situasi kelas yang kurang kondusif.

3) Guru lebih intensif dalam membimbing. Karena dalam metode CTL, guru tidak lagi berperan sebagai pusat informasi. Tugas guru adalah mengelola kelas sebagai sebuah tim yang bekerja bersama untuk menemukan pengetahuan dan ketrampilan yang baru bagi siswa. Siswa dipandang sebagai individu yang sedang berkembang. Kemampuan belajar seseorang akan dipengaruhi oleh tingkat perkembangan dan keluasan pengalaman yang dimilikinya. Dengan demikian, peran guru bukanlah sebagai instruktur atau "penguasa" yang memaksa kehendak melainkan guru adalah pembimbing siswa agar mereka dapat belajar sesuai dengan tahap perkembangannya. 
4) Guru memberikan kesempatan kepada siswa untuk menemukan atau menerapkan sendiri ide-ide dan mengajak siswa agar dengan menyadari dan dengan sadar menggunakan strategi-strategi mereka sendiri untuk belajar. Namun dalam konteks ini tentunya guru memerlukan perhatian dan bimbingan yang ekstra terhadap siswa agar tujuan pembelajaran sesuai dengan apa yang diterapkan semula.

h. Karakteristik model pembelajaran Contextual Teaching and Learning(CTL)

Terdapat lima karakteristik penting dalam proses pembelajaran yang menggunakan pendekatan Kontekstual:
1) Dalam
Pembelajaran
Kontekstual pembelajaran merupakan proses pengaktifan pengetahuan yang sudah ada (activing knowledge). Artinya, apa yang akan dipelajari tidak terlepas dari pengetahuan yang sudah dipelajari. Dengan demikian, pengetahuan yang

akan diperoleh siswa adalah pengetahuan yang utuh yang memiliki keterkaitan satu sama lain.

2) Pembelajaran yang kontekstual adalah pembelajaran dalam rangka memperoleh dan menambah pengetahuan baru (acquiring knowledge). Pengetahuan baru itu dapat diperoleh dengan cara deduktif. Artinya, pembelajaran dimulai dengan mempelajari secara keseluruhan kemudian memperhatikan detailnya.

3) Pemahaman pengetahuan (understanding knowledge) berarti pengetahuan yang diperoleh bukan untuk dihafal, melainkan untuk dipahami dan diyakini.

4) Mempraktikkan pengetahuan dan pengalaman tersebut (applying knowledge). Artinya, pengetahuan dan pengalaman yang diperolehnya harus dapat diaplikasikan dalam kehidupan nyata.

5) Melakukan refleksi (reflecting knowledge) terhadap strategi pengembangan pengetahuan. 
Hal ini dilakukan sebagai umpan balik untuk proses perbaikan dan penyempurnaan strategi.

Adapun karakteristik CTL dalam Zainal Aqib (2013, hlm, 8) yaitu sebagai berikut: kerjasama, saling menunjang, menyenangkan, tidak membosankan, belajar dengan bergairah, pembelajaran terintegrasi, menggunakan berbagai sumber, siswa aktif, sharing dengan teman, siswa kritis guru kreatif, dinding dan loronglorong penuh dengan hasil kerja siswa, peta-peta, gambar, artikel, humor, dan lain-lain, dan laporan kepada orang tua bukan hanya rapor tetapi hasil karya siswa, laporan hasil praktikum siswa, dan lain-lain.

\section{METODE PENELITIAN}

Menurut Sugiono (2016, hlm, 6) metode penelitian dapat diartikan sebagai cara ilmiah untuk mendapatkan data yang valid denga tujuan dapat ditemukan, dikembangkan, dan dibuktikan.

Menurut Suryana (2010, hlm, 10) metode penelitian adalah prosedur atau langkah-langkah dalam mendapatkan pengetahuan ilmiah atau ilmu. Menurut Suyanto, (1997:3) dalam Agus Yunia (2010, hlm. 22), metode yang digunakan dalam penelitian ini adalah metode tindakan kelas yang difokuskan pada situasi belajar mengajar di kelas. Penelitian tindakan kelas merupakan cara yang strategis yang dapat dilakukan oleh guru dalam memahami proses pembelajaran yang terjadi dikelas. Dengan melakukan penelitian tindakan guru dapat: 1) meningkatkan kualitas proses belajar, 2) menjembatani kesenjangan antara teori dan praktek pendidikan.

Ada beberapa bentuk penelitian tindakan, menurut oja dan mulyana (suyanto, 1997:17) dalam Agus Yunia, (2010, hlm. 22), yaitu: 1) guru sebagai peneliti, 2) peneliti tindakan kolaboratif, 3) simultan-teritegrasi, 4) administrasi social eksperimental. Bentukan penelitian kelas yang akan dilaksanakan adalah mengadopsi dari pengelompokan oja dan mulya di mana guru sebagai peneliti, memiliki ciri penting yaitu sangat 
berperannya guru itu sendiri dalam proses penelitian tindakan kelas.

Menurut Drs. Suaidin dalam asmani, (2011, hlm 76) PTK didefinisikan PTK sebagai suatu bentuk kajian reflektif oleh guru sebagai pelaku tindakan yang bertujuan untuk meningkatkan kemantapan rasional dalam melaksanakan tugas keguruannya memperdalam pemahaman terhadap tindakan yang dilakukannya, serta memperbaiki pembelajaran yang dilakukan. Adapun menurut Stephen Kemmis yang dikutip oleh saminanto (2010:2) bahwa PTK adalah suatu bentuk kajian reflektif oleh pelaku tindakan yang dilakukan untuk meningkatkan kemantapan rasional dari tindakan mereka dalam melaksanakan tugas, memperdalam pehaman terhadap tindakan yang dilakukannya, memperbaiki kondisi dimana praktik-praktik pembelajaran tersebut dilakukan serta dilakukan secara kolaboratif.

Menurut Prof. Suharmisi Arikunto Suhardjono (2016:1) dalam bukunya penelitian tindakan kelas mendefinisikan bahwa PTK merupakan penelitian yang memaparkan terjadinya sebabakibat dari perilaku, sekaligus memaparkan apa saja yang terjadi ketika perlakuan diberikan, dan memaparkan seluruh proses sejak awal pemberian perlakuan sampai dengan dampak dari pelakuan tersebut.

\section{PEMBAHASAN}

Berdasarkan hasil penelitian yang dilakukan di SDN Karangasri dengan menggunakan model pembelajaran Contextual Teaching and Learning pada subtema perubahan lingkungan, hasil dari penelitian yang dapat diperoleh peningkatan terhadap pelaksanaan kegiatan pembelajaran dan hasil belajar siswa yang diperoleh setelah pelaksanaan tindakan, adapun pelaksanaan tindakan terdiri dari tiga siklus, yang pertaman pelaksanaan tindakan siklus I, siklus II, dan siklus III. Agar data lebih terperinci bisa dilihat dari uraian berikut ini :
1. Perencanaan
pelaksanaan pembelajaran
dengan 
menggunakan

model

pembelajaran

Contextual

Teaching and Lerning dapat meningkatkan hasil belajar siswa

Sebelum

melakukan

penelitian peneliti observasi terlebih dahulu selama proses pembelajaran berlangsung, peneliti mengamati dan mencatat penemuan. Peneliti kemudian berdiskusi dengan observer untuk merancang pelaksanaan kegiatan pembelajaran agar terlaksana dengan baik. Peneliti menyiapkan rancangan kegiata harus di persiapkan sebelum melaksanakan pembelajaran yaitu membuat Rencana Pelaksanaan Pembelajaran (RPP) yang di dalam nya memuat tujuan pembelajaran, materi ajar, model pembelajaran Contextual Teaching and Learning, metode ceramah, metode tanya jawab, metode diskusi, media hingga sumber belajar yang disertai scenario pembelajaran, dan alokasi waktu agar pelaksanaan pembelajaran lebih tersusun dan terarah. Peneliti menyiapkan lembar pretest dan posttest, lembar kerja kelompok (LKK), lembar penilaian sikap kerjasama dan sikap percaya diri. Penelitian ini dilakaukan di SDN Karangsari di kelas $\mathrm{V}$ pada tema lingkungan sahabat kita subtema perubahan lingkunga dengan menggunakan model pembelajaran Contextual Teaching and Learning. Penelitian ini di bantu oleh observer yaitu guru kelas $\mathrm{V}$ mulai dari awal kegiatan pembelajaran sampai tindakan pembelajaran berhasil.

Adapun hasil penilaian rencana pelaksanaan pembelajaran pada siklus 1 pertemuan 1 mendapatkan nilai 3,2 dan pertemuan 2 mendapatkan nilai 3,3, maka hasil akhir dari siklus I rencana pelaksanaan sebanyak 3,25 dengan kategori baik memperolehan persentase ketuntasan sebanyak 81,25\%. Pada siklus II hasil penilaian rencana pelaksanaan pembelajaran tindakan 1 mendapatkan nilai 3,4 dan pertemuan 2 mendapatkan nilai 3,6, maka hasil akhir dari siklus II rencana pelaksanaan sebanyak 
3,5 dengan kategori baik memperoleh

persentase

ketuntasan berjumlah $87,5 \%$.

Sedangkan pada siklus III hasil penilaian rencana pelaksanaan pembelajaran pertemuan 1 mendapatkan nilai 3,4 dan pertemuan 2 mendapatkan nilai 3,8, maka hasil penilaian akhir dari siklus III rencana pelaksanaan pembelajaran sebanyak 3,6 dengan kategori sangat baik memperoleh persentase ketuntasan berjumlah $90 \%$. Dalam siklus III mengalami peningkatan mulai dari siklus I sampai dengan siklus III.

\section{Pelaksanaan}

Pemebelajaran

Menggunakan

Pembelajaran

Contextual

Teaching and Learning untuk Meningkatkan Hasil Belajar Siswa pada Subtema Perubahan Lingkungan

Pelaksanaan

proses

pembelajaran yang dilaksanakan pada siklus I, siklus II, dan siklus III dengan menggunakan model pembelajaran Contextual Teaching and Learning dapat meningkat hasil belajar pada subtema perubahan lingkungan di SDN Karangsari pada kelas V. Agar lebih jelas dapat dilihat dari pada penjelasan di bawah ini.

a. Siklus I

Pada pelaksanaan siklus I masih belum optimal karena dalam proses pembelajaran menurut observer dalam melakukan diskusi guru masih belum seimbang dalam membimbing setiap kelompoknya sehingga guru terfokus hanya beberapa arah dan siswa tidak di perhatikan kurang kondusif, sehingga siswa lainnya mengobrol dengan teman kelompoknya, kegiatan pembelajaran menjadi tidak sesuai dengan yang diharapkan. Untuk mengatasinya peneliti berdiskusi bersama observer agar pembelajaran pada tindakan selanjutnya dapat meningkat dan sesuai dengan yang diharapkan.

b. Siklus II

Pada pelaksanaan siklus II ini sudah mulai meningkat dengan baik, kegiatan pembelajaran dengan baik, siswa sudah mulai aktif untuk bertanya, maju kedepan 
untuk menjelaskan hasil dikusinya, terlihat dari banyak siswa yang memberanikan diri untuk menjawab pertanyaan dan kegiatan diskusi mulai terbimbing. Masih ada kekurangan dalam menyesuaikan alokasi waktu pembelajaran sehingga waktu pembelajaran melebihi dan kegiatan yang seharusnya dilakukan di luar ruangan menjadi di dalam kelas faktor lingkungan yang kurang memadai. Sehingga bersama observer berdiskusi untuk mengatasi mengevaluasi agar proses pembelajaran tersusun dan terarahkan sesuai dengan yang diharapkan.

c. Siklus III

Pada pelaksanaan siklus III sudah meningkat di lihat dari aktivitas siswa dalam bertanya, berani pengemukan pendapat saat berjalannya diskusi, siswa mulai berani tampil di depan untuk menjelaskan hasil diskusi dibandingkan dengan siklus sebelumnya. Selain aktivitasnya siswa yang meningkat, perkembangan hasil belajarpun meningkat di lihat dari penilai pretest, posttest, lembar kerja kelompok, keterampilan, sikap kerjasama dan sikap peracaya diri sudah mulai memenuhi kriteria ketuntasan.

Berdasarkan penjelasan di atas bahwa pelaksanaan pembelajran setiap siklusnya mengalami peningkatan mulai dari siklus I, II dan siklus III hasil pelaksanaan saat proses mengajar guru pada setiap tindakannya, tebukti dari hasil perolehan siklus I tindakan 1 mendapatkan nilai 3,4 dan tidakan 2 mendapatkan nilai 3,57, maka hasil akhir siklus I mendapatkan nilai sebanyak 3,48 persentasenya ketuntasan sebanyak $87 \%$ di kategorikan sangat baik. Hasil perolehan pada siklus II tindakan 1 mendapatkan nilai sebanyak 3,52 dan tindakan 2 mendapatkan nilai sebanyak 3,57, maka hasil akhir siklus II mendapatkan nilai sebanyak 3,54 persentase ketuntasannya sebanyak 88,62\% di kategorikan sangat baik sedangkan hasil penilaian siklus III tindakan 1 mendapatkan nilai sebanyak 3,57 dan tindakan 2 mendapatkan nilai 
sebanyak 3,62, maka hasil akhir dari siklus III mendapatkan nilai sebanyak 3,59 persentase mendapatkan nilai sebanyak 89,75\% di kategorikan sangat baik.

\section{Peningkatan Hasil Belajar}

Siswa dengan Menggunakan Model

Pembelajaran

Contextual Teaching and Learning

Peningkatan hasil belajar siswa diperoleh berdasarkan hasil belajar pretest, posttest, lembar kerja kelompok, keterampilan, sikap kerjasama dan sikap percaya diri. Untuk lebih jelas lagi berikut ini penjelasan hasil belajar siswa dari setiap siklusnya sebagai berikut:

\section{a. Data Hasil Belajar Siklus I}

Data hasil belajar pada siklus I ini di peroleh dari kegiatan pembelajaran siswa secara individu terdiri dari penilaian pretest, poste, lembar kerja kelomok (LKK), penilaian keterampilan, pada subtema perubahan lingkungan.

1) Hasil belajar pretest dan posttest

Pada siklus I pretest terdiri dari 10 soal dan posttest terdiri 10 soal, adapun hasil penilai pretest dan posttest, siswa yang tuntas sebanayak 15 orang dari jumlah keseluruhan persentase mencapai nilai sebanyak 39,47\%, siswa yang tidak tuntas sebanyak 23 orang dari jumlah keseluruhan persentase mencapai nilai sebanyak $60,25 \%$.

2) Lembar kerja kelompok

Pada siklus ini di bagi menjadi 5 kelompok yang setiap kelompoknya terdiri dari 7 sampai 8 orang, adapun hasil penilaian lembar kerja kelompok siwa yang tuntas sebanyak 22 orang dari jumlah keseluruhan 38 orang persentase mencapai nilai 57,89\%, sedangkan siswa yang tidak tuntas sebanyak 16 orang dari jumlah keseluruhan 38 orang persentase mencapai $42,10 \%$.

3) Hasil penilaian keterampilan

Hasil penilaian keterampilan pada siklus I ini siswa yang tuntas sebanyak 16 orang dari jumlah keseluruhan 38 orang persentase mencapai 42,10\%, sedangkan siswa yang tidak tuntas sebanyak 22 orang dari jumlah keseluruhan 
38 orang persentase mencapai $57,89 \%$.

\section{b. Data Hasil Belajar Siklus II}

Pada siklus II ini hasil belajar siswa diperoleh dari penilaian pretest, posttest, lembar kerja kelompok, dan penilaian keterampilan. Agar lebih jelas lagi dapat di lihat di bawah ini.

1) Hasil Penilaian pretest dan posttest

Lembar pretest dan posttest terdiri dari 10 soal, adapun hasil penilaian pretest dan posttest yaitu: a. Siswa yang tuntas sebanyak 20 orang dari jumlah keseluruhan 38 orang persentase mencapai $52,63 \%$, b. Siswa yang tidak tuntas sebanyak 18 orang dari jumlah keseluruhan yaitu 38 orang persentase dari siswa yang tidak tuntas mencapai $47,36 \%$.

2) Hasil Penilaian Lembar Kerja Kelompok (LKK)

Hasil penilaian lembara kerja kelompok siswa yang tuntas sebanyak 29 orang dari jumlah keseluruhan yaitu 38 orang, persentase dari siswa yang tuntas mencapai $76,31 \%$, sedangkan siswa yang tidak tuntas sebanyak 9 orang dari jumlah keseluruhan yaitu 38 orang, persentase dari siswa yang tidak tuntas mencapai $23,68 \%$.

3) Penilaian Keterampilan

Penilaian keterampilan pada sisklus II ini siswa yang tuntas sebanyak 25 orang dari jumlah keseluruhan yaitu 38 orang, persentase siswa yang tuntas mencapai 65,78\%, sedangkan siswa yang tidak tuntas sebanyak 13 orang dari jumlah keseluruhan yaitu 38 orang, persentase dari siswa yang tidak tuntas mencapai $34,21 \%$.

\section{c. Data Hasil Belajar Siklus III}

Adapun hasil belajar pada siklus III meliputi: penilaian pretest, posttest, lembar kerja kelompok (LKK), dan lembar keterampilan, agar lebih jelas dapat dilihat di penjelasan di bawah ini.

1) Hasil Penilaian Pretest dan Posttest

Lembar pretes dan posttest terdiri dari 10 soal, adapun hasil penilaian pretest dan posttest yaitu: a. Siswa yang tuntas sebanyak 33 orang dari jumlah 
keseluruhan 38 orang persentase mencapai $86,84 \%$, b. Siswa yang tidak tuntas sebanyak 5 orang dari jumlah keseluruhan yaitu 38 orang persentase dari siswa yang tidak tuntas mencapai $13,15 \%$.

2) Hasil Penilaian Lembar Kerja Kelompok (LKK)

Hasil penilaian lembara kerja kelompok siswa yang tuntas sebanyak 38 orang dari jumlah keseluruhan yaitu 38 orang, persentase dari siswa yang tuntas mencapai $100 \%$ semuanya tuntas mencapai KKM.

3) Hasil Penilaian Keterampilan

Penilaian keterampilan pada sisklus III ini siswa yang tuntas sebanyak 28 orang dari jumlah keseluruhan yaitu 38 orang, persentase siswa yang tuntas mencapai 73,68\%, sedangkan siswa yang tidak tuntas sebanyak 10 orang dari jumlah keseluruhan yaitu 38 orang, persentase dari siswa yang tidak tuntas mencapai $26,3 \%$.

Berdasarkan penjelasan diatas tentang hasil belajar siswa setiap siklusnya mengalami peningkat mulai dari pretest, posttest, lembar kerja kelompok (LKK) dan lembar keterampilan.

$$
\text { Berdasarkan analisis }
$$

perbandingan data hasil belajar siswa menunjukkan adanya peningkatan hasil belajar siswa dengan menggunakan model pembelajaran Contextual Teaching and Learning pada tema lingkungan sahabat kita subtema prubahan lingkungan di kelasa $\mathrm{V}$ SDN Karangsari. Setelah menggunakan model pembelajaran Contextual Teaching and Learning mengalami peningkatan baik dilihat dari pretest, posttest, lembar kerja kelompok ataupun keterampilan semuanya mengalami peningkatan padat dilihat dari setiap siklusnya. Siklus I siswa yang tuntas sebanayak 15 orang dengan rataratakan mencapai 39 yang mencapai kriteria ketuntaasan, pada siklus II siswa yang tuntas mencapai 20 orang dengan ratarata 52 yang mencapai kriteria ketuntasan dan pada siklus III siswa yang tuntas mencapai 33 orang dengan rata-rata mencapai 86 yang mencapai kriteria 
ketuntasan. Sehingga dapat disimpulkan bahwa hasil belajar peserta didik sudah mencapai target yang diharapkan yaitu nilai rata-rata lebih dari 70 dan yang memperoleh nilai $>70$ lebih dari $80 \%$.

\section{E. SIMPULAN}

1. Berdasrkan hasil penelitian tindakan yang berlangsung selama tiga siklus ini dapat di simpulkan bahwa pada tema lingkungan sahabat kita subtema perubahan lingkungan dengan menggunakan model pembelajaran Contextual Teaching and Learning untuk meningkat hasil belajar siswa di SDN Karangsari kelas $\mathrm{V}$ Kabupaten Cianjur. Pada setiap siklusnya mengalami peningkatan baik pada hasil pembelajaran ataupun sikap. Maka berdasarkan hasil penelitian diperoleh kesimpulan sebagai berikut.

2. Aktivitas belajar siswa ketika menggunakan model Contextual Teaching and Learning pada penilaian pretes dan posttest di kelas V SDN Karangsari dapat diketahui dari data siklus I siswa yang tuntas hanya beberapa orang dapat dilihat dari persentasenya yaitu sebanyak tiga puluh sembilan koma empat puluh tujuh persen, sedang pada siklus II mengalami peningkatan, siswa yang tuntas dapat dilihat dari persentasenya yaitu sebanyak lima puluh dua koma enam puluh tiga persen yang mencapai kriteria ketuntasan, dan pada siklus III mengalami peningkatan hampir semuanya mencapai kriteria ketuntasan dapat dilihat dari persentase yaitu sebanyak delapan puluh enam koma delapan puluh empat persen yang tuntas. Berdasarkan data tersebut, peningkatan hasil observasi pada aktivitas siswa dalam pembelajaran menggunakan Contextual Teaching and Learning membuat siswa menjadi aktif, kreatif atau bekerja sama dengan teman-temannya. Sehingga siswa dapat 
menerapkan di kehidupan sehari-hari.

3. Sikap kerjasama, sikap percaya diri dan hasil belajar pada tema lingkungan sahabat kita subtema perubahan lingkungan sebelum menggunakan model pembelajaran Contextual Teaching and Learning hasil belajar siswa rendah, dapat dilihat dari data siklus I yang mulai ada peningkatan dapat dilihat dari persentasenya yaitu sebanyak empat puluh dua persen, sedangkan pada siklus II mengalami peningkatan dari sebelumnya dapat dilihat dari persentasenya yaitu sebanyak enam puluh persen yang mencapai kriteria ketuntasan, dan pada siklus III mengalami peningkatan hampir semuanya mencapai kriteria ketuntasan dapat dilihat dari persentasenya yaitu sebanyak tujuh puluh satu persen yang tuntas. Penelitian ini dilakukan di SDN Karangsari Kabupaten Cianjur setelah menggunakan model pembelajaran Contextual
Teaching and Learning ada peningkatan.

4. Penggunaan model pembelajaran Contextual Teaching and Learning dapat meningkatkan hasil belajar siswa di kelas V . Hasil belajar keterampilan pada setiap siklus membuktikan adanya peningkatan, setiap siklusnya dapat dilihat dari persentase ketuntasan banyak yang mencapai KKM, adapun rincian dari setiap siklusnya yaitu siklus I yang mencapai kriteria ketuntasan dapat dilihat dari persentasenya yaitu sebanyak empat puluh dua koma sepuluh persen, sedangkan pada siklus II yang mencapai kriteria ketuntasan dapat dilihat dari persentasenya yaitu sebanyak enam puluh lima koma tujuh puluh delapan persen dan pada siklus III yang mencapai kriteria ketuntasan dapat dilihat dari persentasenya yaitu sebanyak tujuh puluh tiga koma enam puluh delapan persen. Dengan demikian bahwa pembelajaran dengan menggunakan 
Contextual Teaching and Learning efektip dalam meningkatkan hasil belajar siswa pada subtema perubahan lingkungan di kelas V SDN Karangsari.

\section{DAFTAR PUSTAKA}

Anisah Hilmayani. (2016).

Penerapan Model Contextual Teaching and Learning untuk Meningkatkan Hasil Belajar dalam Pembelajaran IPS Materi Kegiatan Ekonomi dalam Memanfaatkan Sumber Daya Alam. Bandung: Tidak diterbitkan.

Arifin Zainal. (2011). Evaluasi Pembelajaran. Bandung: PT. Remaja Rosdakarya.

Arikunto. (2015). Penelitian

Tindakan Kelas. Jakarta: PT Bumi Aksara.

Aqib, Zainal. (2014). Model-model media dan strategi pembelajaran kontekstual (inovatif). Bandung: CV Yrama Widaya.

Cahyo N. Agus. (2013). Panduan Aplikasi Teori-teori Belajar Mengajar Teraktual dan
Terpopuler.Jogjakarta: Diva Press

Conny. (2012). Belajar dan Pembelajaran Prasekolah dan Sekolah Dasar. Jakarta: PT. Macanan Jaya Cemerlang

Dikusumah, Susanto Anry. (2012).

Penggunaan Model

Pembelajaran Problem Based Learning untuk meningkatkan sikap rasa ingin tahu dan Hasil Belajar Siswa Pada Pembelajaran IPS. Bandung: Tidak diterbitkan.

Elaine b. Johnson, Ph, D. (2011). CTL Contextual Teaching and Learning Menjadi Kegiatan Belajar Mengajar Mengasyikkan dan Bermakna. Bandung: Kaifa.

Ganisha Berliani Novi. (2016).

Penggunaan Model Cooperative Type Makea Match Untuk Meningkatkan Kerjasama dan Hasil Belajar Siswa pada Pembelajaran IPS Kelas IV SDN Mekarlaksana Cianjur. Bandung: Tidak diterbitkan.

Hanafiah Nanang dan Suhana Cucu. (2012). Konsep Strategi 
Pembelajaran. Bandung: PT.

Refika Aditama.

Hartadi Titut. (2011). 4 Langkah

Praktis Menyusun PTK.

Karawang: Tidak Diterbitkan.

Ikka Rihhatul A'isy (2016) Upaya

Meningkatkan Hasil Belajar

Siswa dengan Menggunakan

Model Contextual Teaching

and Learning pada

Pembelajaran IPS di Kelas IV

SDN Girimukti. Bandung:

Universitas Pendidikan

Indonesia

Iskandar, Dadang dan Narsim.

(2015). Penelitian Tindakan

Kelas dan Publikasiny.

Cilacap: Ihya Media.

Karitas Diana, dkk. (2014). Buku

Guru "Lingkungan Sahabat

Kita". Jakarta: Kementerian

Pendidikan dan Kebudayaan.

Karitas Diana, dkk. (2014). Buku

Siswa "Lingkungan Sahabat

Kita". Jakarta: Kementerian

Pendidikan dan Kebudayaan.

Komalasari Kokom. (2011).

Pembelajaran Kontekstual

Konsep dan Aplikasi.

Bandung: PT Refika Aditama.
Mulyana Dadang dan Jusuf Eddy, dkk. (2017). Panduan Penulisan Karya Tulis IImiah (KTI). Bandung: Fkip Universitas Pasundan Bandung

Mujiono dan Dimyati. (2013). Belajar dan Pembelajaran. Bandung: Alfabeta

Permendikbud No. 81 A. (2013). Implementasi Kurikulum 2013. Jakarta: Tidak diterbitkan.

Puspitasi Dewi \& Hardini Sriani. (2012). Strategi Pembelajaran Terpadu (Teori, Konsep \& Implementasi). Yogyakarta: Familia (Group Relasi Inti Media)

Rusman. (2012). Model-Model

Pembelajaran

Mengembangkan

Profesionalisme Guru. Jakarta:

PT Rajagrafindo.

Sagala Syaiful. (2011). Konsep

Dasar dan Makna

Pemblajaran. Bandung:

Alfabeta.

Sanjaya Wina. (2010). Pencenaan dan Desain Sistem Pembelajaran. Jakrta: PT Fajar Interpratama 
Sardiman. (2011). Interaksi dan Motivasi Belajar Mengajar. Jakarta: PT. Rajagrafindo Persada

Solihatin Etin. (2012). Strategi Pembelajaran PPKN. Jakarta: PT. Bumi Aksara

Sudjana Nana. (2013). Penilaian Hasil Proses Belajar Mengajar. Bandung: PT. Remaja Rosdakarya.

Sugiono. (2016). Metode Penelitian Pendidikan. Bandung: Alfabeta

Supardi, dkk. (2016). Penelitian

Tindakan Kelas. Jakarta: PT

Bumi Aksara

Suprijono Agus. (2015).

Cooperative Learning Teori \& Aplikasi PAIKEM. Yogyakarta:

Pustaka Pelajar.

Suryana. (2010). Metode

Penelitian Tindakan Kelas.

Bandung: Alfabeta

Surya Mohamad. (2014). Psikologi

Guru Konsep dan Aplikasi dari

Guru, untuk Guru. Bandung:

Alfabeta.

Taniredja Tuniredja, dkk. (2011).

Model-model Pembelajaran

Inovatif. Bandung: Alfabeta.
Trianto Ibnu Badar al-Tabany. (2014). Mendesain Model Pembelajaran Inovatif, Progresif, dan Kontekstual Konsep, Landasan, dan Implementasinya Pada Kurikulum 2013 (Kurikulum Tematik Integratif/KTI). Bandung: Prenadamedian Group.

Wahyuni, Ida. (2012). Penggunaan Pendekatan Matematika Realistik Untuk Meningkatkan Pemahaman Konsep Melakukan Operasi Perkalian dan Pembagian Pada Pembelajaran Matemitak. Bandung: Tidak diterbitkan Wardoyo Sigit Mangun. (2013). Pembelajaran Konstruktivisme Teori dan Aplikasi Pembelajaran dalam Pembentukan Karakter. Bandung: Alfabeta.

Wiriaatmadja Rochiati. (2013). Metode Penelitian Tindakan Kelas. Bandung: PT. Remaja Rosdakarya

Yuliana Nurrizki (2016) Penerapan Model Contextual Teaching and Learning Untuk 
Didaktik : Jurnal Pendidikan Guru Sekolah Dasar, ISSN : 24775673

Sekolah Tinggi Keguruan dan IImu Pendidikan Subang Volume II Nomor 2, Juli 2017

\begin{tabular}{cl}
\hline $\begin{array}{l}\text { Meningkatkan Hasil Belajar } \\
\text { dalam Pembelajaran IPS }\end{array}$ & Meningkatkan \\
Materi Kegiatan Ekonomi & pada Pembelajaran IPS di SD. \\
dalam Pemanfaatan Sumber & Bandung: Tidak diterbitkan \\
$\begin{array}{l}\text { Daya Alam. Bandung: Tidak } \\
\text { diterbitkan }\end{array}$ & Undang No. 14 Tahun 2015 \\
Yunia Agus (2010) Pendekatan & Tentang Pendidikan Guru dan \\
Keterampilan Proses untuk & Dosen.
\end{tabular}

